\title{
PENGAKUAN PENDAPATAN DENGAN METODE PERSENTASE PENYELESAIAN BERDASARKAN PSAK NO. 34
}

\author{
Evi Nurjanah
}

\author{
Fakultas Ekonomi, Universitas Islam Negeri Maulana Malik Ibrahim Malang \\ Jl. Gajayana 50 Malang Telp. 0341-551354 \\ Email: evi.nurjanah72@yahoo.co.id
}

Abstract

This study aims to determine the method used in recognizing revenue on longterm construction. This study also aims to determine whether the recognition of revenue on long-term construction contracts are carried out in accordance with generally accepted accounting standards. In addition, to determine the appropriate revenue recognition methods Generally Accepted Accounting Standards.Object of this research was conducted at PT. X which is a company engaged in a long-term provider of construction services. Object of research data is performed only on income related to the project Mall, Malang cover the period 2011 to 2015. The analytical method used is qualitative method with descriptive approach. The results showed that $P T$. $X$ recognizes revenue based on cash receipts (cash basis). So that the revenue recognized in the PT. $X$ admittedly not based on the matching principle of revenue that occurred in that period with the costs incurred to earn income in the period. In addition, PT. X uses nominal account in the form of development cost mall in recognizing expenses related to procurement of long-term construction contracts. So PT. X can not provide detailed information related to the building construction in progress. In addition, the fee accounts can not be transferred when the handing over of assets construction that has been completed to the customer. Recognition of revenue and costs will also affect the incidence of deferred tax liabilities. In addition, recognition of revenues and expenses is not in accordance with generally accepted accounting standards, especially PSAK No. 34, Accounting for Construction Contracts. Under PSAK No. 34 that the entity 
using the percentage of completion method in recognizing revenue on longterm construction contracts.

Keywords: income, expenses, construction contracts, PSAK 34, percentage of completion method

Abstrak

Penelitian ini bertujuan untuk mengetahui metode yang digunakan dalam mengakui pendapatan atas kontruksi jangka panjang. Penelitian ini juga bertujuan untuk mengetahui apakah pengakuan pendapatan atas kontrak kontruksi jangka panjang yang dilakukan telah sesuai dengan Standar Akuntansi yang Berlaku Umum. Selain itu juga untuk mengetahui metode pengakuan pendapatan yang sesuai Standar Akuntansi yang berlaku umum. Obyek penelitian ini dilakukan pada PT. X yang merupakan perusahaan yang bergerak dalam bidang penyedia jasa kontruksi jangka panjang. Obyek data penelitian yang dilakukan hanya pada laba rugi yang berkaitan dengan proyek Mall, Malang periode tahun 2011 sampai dengan 2015. Metode analisis yang digunakan adalah metode kualitatif dengan pendekatan deskriptif. Hasil penelitian menunjukkan bahwa PT. X mengakui adanya pendapatan berdasarkan atas penerimaan kas (cash basis). Sehingga pendapatan yang diakui pada PT. X diakui tidak berdasarkan prinsip penandingan antara pendapatan yang terjadi pada periode tersebut dengan biaya yang dikeluarkan untuk memperoleh pendapatan pada periode tersebut. Selain itu, PT. X menggunakan akun nominal berupa biaya pembangunan mall dalam mengakui pengeluaran biaya yang terkait pengadaan kontrak kontruksi jangka panjang. Sehingga PT. X tidak dapat memberikan informasi mendetail terkait bangunan kontruksi dalam proses. Selain itu, akun biaya tersebut tidak dapat dialihkan ketika terjadi penyerahan aset kontruksi yang telah selesai kepada pemesan. Pengakuan pendapatan dan biaya ini juga akan mempengaruhi timbulnya kewajiban pajak tangguhan. Selain itu, pengakuan pendapatan dan biaya ini belum sesuai dengan Standar Akuntansi yang berlaku umum, khusunya PSAK No. 34 tentang Akuntansi Kontrak Kontruksi. Berdasarkan PSAK No. 34 bahwa entitas menggunakan metode persentase penyelesaian dalam mengakui pendapatan atas kontrak kontruksi jangka panjang

Kata kunci: pendapatan, biaya, kontrak kontruksi, PSAK 34, metode persentase penyelesaian

\section{PENDAHULUAN}

Informasi laba perusahaan bukan sekadar informasi yang berguna untuk menarik perhatian pihak eksternal untuk melakukan investasi maupun untuk melakukan transaksi dengan perusahaan. Namun, informasi laba merupakan suatu informasi 
yang dapat digunakan oleh suatu perusahaan dalam mengambil suatu keputusan yang akan diterapkan di perusahaan tersebut.

Salah satu penentu besarnya laba perusahaan adalah pendapatan. Indikator sederhana dari keberhasilan suatu perusahaan adalah memperoleh pendapatan yang lebih tinggi pada suatu periode dibandingkan dengan periode sebelumnya. Pendapatan harus disajikan secara tepat dan sesuai dengan pendapatan yang sebenarnya diperoleh oleh perusahaan pada suatu periode tertentu. Pengakuan pendapatan merupakan saat dimana suatu perusahaan mengakui suatu transaksi sebagai pendapatan perusahaan. Sedangkan pengukuran pendapatan merupakan penentuan besar jumlah pendapatan yang harus diakui perusahaan pada setiap transaksi yang terjadi di suatu periode tertentu. Penentuan bagaimana perusahaan mengakui pendapatan sangat berpengaruh terhadap laba.

Adanya beberapa pendekatan pengakuan pendapatan berdasarkan persentase penyelesaian merupakan suatu permasalahan bagi perusahaan. Perusahaan harus dapat menetukan pendekatan pengakuan untuk pendapatan secara tepat agar pengakuan pendapatan dapat disajikan pada laporan keuangan secara benar berdasarkan PSAK yang mengatur yakni PSAK No. 23 tentang pendapatan sedangkan metode pengakuannya diatur dalam PSAK No. 34 tentang kontrak kontruksi. PSAK 23 paragraf 20 menyatakan bahwa pengakuan pendapatan dengan mengacu pada tingkat penyelesaian dari suatu transaksi sering disebut sebagai metode persentase penyelesaian.

PT. X merupakan perusahaan yang bergerak di bidang penyedia jasa kontruksi. Perusahaan ini melakukan pengakuan pendapatan dengan metode kontrak selesai. Salah satu proyek yang dikerjakan dan baru selesai pada tahun 2015 adalah mall yang terletak di Jl. MT Haryono, Malang. Proyek mall dikerjakan selama 5 tahun. Rincian biaya produksi telah ditentukan secara rinci pada setiap periode akuntansi dimana proyek tersebut berlangsung dan telah dilaporkan pada laporan laba rugi komprehensif. Namun pendapatan baru diakui pada saat proyek selesai yaitu pada tahun 2015. Sehingga pada tahun-tahun sebelumnya jumlah pendapatan yang terkait dengan proyek mall belum nampak pada laporan laba rugi komprehensif. Sehingga laporan keuangan yang disajikan belum dapat dikatakan akurat. Hal ini sangat mempengaruhi pihak-pihak yang berkepentingan dengan laporan keuangan dalam pengambilan keputusan.

\section{KAJIAN TEORI}

\section{Pendapatan}

Berdasarkan PSAK No. 23 (Revisi 2015) disebutkan bahwa yang dimaksud dengan pendapatan adalah arus kas masuk bruto dari manfaat ekonomi yang timbul dari aktivitas normal entitas selama suatu periode jika arus masuk tersebut mengakibatkan kenaikan ekuitas yang tidak berasal dari kontribusi penanam modal. 
Berdasarkan PSAK No. 23 paragraf 20 menjelaskan bahwa jika hasil transaksi yang terkait dengan penjualan jasa dapat diestimasi secara andal, maka pendapatan sehubungan dengan transaksi tersebut diakui dengan mengacu pada tingkat penyelesaian dari transaksi pada akhir periode pelaporan. Hasil transaksi dapat diestimasi secara andal jika seluruh kondisi berikut ini dipenuhi: 1) jumlah pendapatan dapat diukur dengan andal; 2) kemungkinan besar manfaat ekonomi sehubungan dengan transaksi tersebut akan mengalir ke entitas; 3) tingkat penyelesaian dari suatu transaksi pada pada akhir periode pelaporan dapat diukur secara andal; dan 4) biaya yang timbul untuk transaksi dan biaya untuk menyelesaikan transaksi tersebut dapat diukur secara andal.

Paragraf 21 menjelaskan bahwa pengakuan pendapatan dengan mengacu pada tingkat penyelesaian dari suatu transaksi sering disebut sebagai metode persentase penyelesaian. Dengan metode ini, pendapatan diakui dalam periode akuntansi pada saat jasa diberikan.

Paragraf 24 menjelaskan bahwa tingkat penyelesaian transaksi dapat ditentukan dengan berbagai metode. Entitas menggunakan metode yang dapat mengukur dengan andal jasa yang diberikan. Bergantung pada sifat transaksi, metode tersebut dapat mencakup: 1) survei pekerjaan yang telah dilaksanakan; 2) jasa yang dilakukan hingga tanggal tertentu sebagai persentase dari total jasa yang harus dilakukan; atau 3) proporsi biaya yang timbul hingga tanggal tertentu dibagi estimasi total biaya transaksi tersebut. Hanya biaya yang mencerminkan jasa yang dilaksanakan hingga tanggal tertentu yang dimasukkan dalam biaya yang terjadi hingga tanggal tersebut. Hanya biaya yang mencerminkan jasa yang dilakukan atau yang akan dilakukan, dimasukkan ke dalam estimasi total biaya transaksi tersebut. Pembayaran berkala dan uang muka yang diterima dari pelanggan sering kali tidak mencerminkan jasa yang dilakukan.

\section{Prinsip Penandingan}

Prinsip penandingan menyatakan bahwa beban-beban harus diakui dalam periode yang sama dengan satu kesatuan dengan pendapatan. Hubungan antara pendapatan dan beban dalam proses menandingkan tergantung pada salah satu dari 4 (empat) kriteria berikut (Belkaoui dalam Ratunuman, 2013):

1. Penandingan langsung yang telah terpakai (expired cost) dengan suatu pendapatan (misalnya harga pokok penjualan dikaitkan dengan penjualan terkait).

2. Penandingan langsung dari beban yang telah terpakai pada periode tersebut (miasalnya, gaji karyawan untuk periode tersebut).

3. Alokasi beban sepanjang periode yang memperoleh manfaat (misalnya, depresiasi). 
4. Menjadikan beban semua biaya lain dalam periode terjadinya, kecuali jika dapat ditunjukan bahwa biaya tersebut masih memiliki manfaat di masa mendatang.

\section{Metode Pengakuan Pendapatan}

PSAK No. 34 (Revisi 2015) paragraf 25 menjelaskan bahwa pengakuan pendapatan dan beban dengan memerhatikan tahap penyelesaian suatu kontrak sering disebut sebagai metode persentase penyelesaian. Menurut metode ini, pendapatan kontrak dihubungkan dengan biaya kontrak yang terjadi dalam mencapai tahap penyelesaian tersebut, sehingga pendapatan, beban, dan laba yang dilaporkan dapat diatribusikan menurut penyelesaian pekerjaan secara proporsional.

Paragraf 30 menjelaskan bahwa tahap penyelesaian suatu kontrak dapat ditentukan dalam berbagai cara. Entitas menggunakan metode yang mengukur secara andal pekerjaan yang dilakukan. Bergantung pada sifat kontrak, metode tersebut antara lain meliputi:

(a) Proporsi biaya kontrak yang terjadi untuk pekerjaan yang dilaksanakan sampai tanggal perhitungan dibandingkan dengan estimasi total biaya kontrak;

(b) Survei atas pekerjaan yang telah dilaksanakan; dan

(c) Penyelesaian suatu bagian secara fisik dari pekerjaan kontrak.

Paragraf 32 menjelaskan bahwa jika hasil kontrak konstruksi tidak dapat diestimasi secara andal:

(a) Pendapatan diakui hanya sebesar biaya yang telah terjadi sepanjang biaya tersebut diperkirakan dapat dipulihkan; dan

(b) Biaya kontrak diakui sebagai beban pada periode terjadinya. 


\section{Kerangka Berpikir}

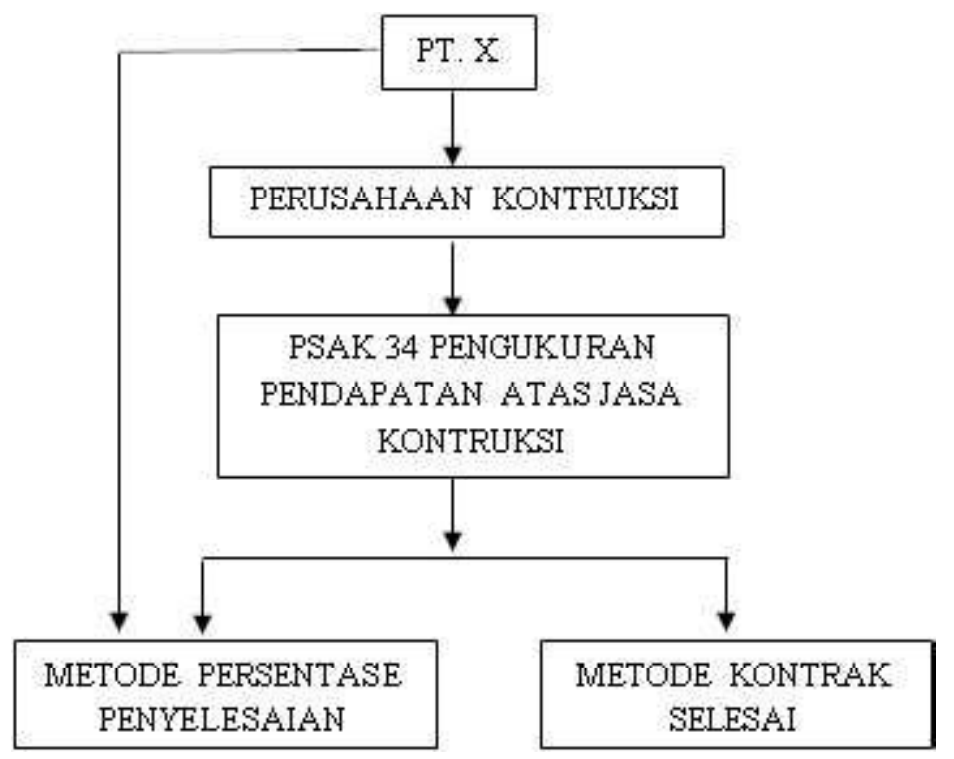

\section{Gambar 1. Kerangka Berfikir}

Berdasarkan kerangka konsep di atas, maka penelitian ini dimulai dari analisis terhadap metode pengakuan pendapatan atas kontrak kontruksi jangka panjang pada PT. X. Selanjutnya disesuaikan dengan metode yang diperbolehkan oleh Standar Akuntansi yang Berlaku Umum terkait pengakuan pendapatan atas kontrak kontruksi jangka panjang yaitu PSAK No. 34. Hasil yang akan diperoleh dari penelitian ini akan menunjukkan bagaimana pengakuan pendapatan kontrak atas kontruksi jangka panjang pada PT. X yang telah sesuai dengan PSAK No. 34 yaitu dengan menggunakan metode persentase penyelesaian.

\section{METODE PENELITIAN}

Penelitian ini menggunakan pendekatan penelitian kualitatif. Penelitian kualitatif dapat menunjukkan kehidupan masyarakat, sejarah, tingkah laku, fungsionalisasi organisasi, pergerakan sosial, dan hubungan keberabatan (Ghoni \& Almanshur. 2012:25)

Jenis penelitian ini adalah penelitian deskriptif kualitatif. Data yang dikumpulkan berupa kata-kata, gambar dan bukan angka. Data tersebut mungkin berasal dari naskah wawancara, catatan lapangan, video-tape, dokumen pribadi, catatan atau memo, dan dokumen resmi lainnya. Pada penulisan laporan demikian, peneliti menganalisis data yang sangat kaya dan sejauh mungkin dalam bentuk aslinya. Hal itu, hendaknya dilakukan seperti orang merajut benang sehingga setiap bagian ditelaah satu demi satu (Ghoni \& Almanshur. 2012: 34-35). 
Jenis data yang digunakan dalam penelitian ini adalah data primer dan data sekunder. Data primer adalah data langsung yang dikumpulkan oleh peneliti dari sumber utama yaitu PT X. Data sekunder adalah data yang diperoleh langsung oleh peneliti dari pihak lain yang telah diolah menjadi bentuk jadi dan relevan dengan penelitian ini.

Teknik analisa data kualitatif untuk proses analisis data dalam penelitian ini. Dalam menganalisa penelitian kualitatif terdapat beberapa tahapan-tahapan yang perlu dilakukan diantaranya (Sidi, 2009:14): mengorganisasikan data; menguji asumsi atau permasalahan yang ada terhadap data; mencari alternatif penjelasan bagi data; dan menulis hasil penelitian.

\section{PEMBAHASAN}

PT. X mengakui adanya pendapatan berdasarkan atas penerimaan kas (cash basis). Selain itu, diketahui bahwa perusahaan mengakui seluruh biaya yang dikeluarkan untuk proses pembangunan mall dalam satu akun yaitu biaya pembangunan mall. Dapat disimpulkan bahwa pengakuan pendekatan yang dilakukan oleh PT. X belum mencerminkan adanya pengakuan pendapatan yang sesuai dengan standar akuntansi yang berlaku umum. Sehingga pendapatan yang diakui pada PT. X diakui tidak berdasarkan prinsip penandingan antara pendapatan yang terjadi pada periode tersebut dengan biaya yang dikeluarkan untuk memperoleh pendapatan pada periode tersebut, serta pendapatan diakui terlalu rendah.

Ketika perusahaan mengakui pengeluaran untuk pembangunan kontruksi sebagai biaya, maka ketika perusahaan melakukan penyerahan tangguhan kontruksi, akun biaya tersebut tidak dapat dialihkan. (Kieso dan Weygandt, 2007: 521) menjelaskan ada dua metode akuntansi yang sangat berbeda untuk kontrak kontruksi jangka panjang yang diakui oleh profesi akuntansi salah satunya adalah metode persentase penyelesaian. Pada metode ini pendapatan dan laba kotor diakui setiap periode berdasarkan kemajuan proses kontruksi, yaitu presentase penyelesaian, biaya konstruksi ditambah laba kotor yang dihasilkan sampai hari ini diakumulasi dalam sebuah akun persediaan (konstruksi dalam proses), dan termin diakumulasi dalam akun kontrak persediaan (tagihan atas konstruksi dalam proses). Sehingga akun persediaan dalam proses tersebut dapat dialihkan ketika terjadi penyerahan kepada pelanggan.

Pengakuan pendapatan dari kontrak kontruksi jangka panjang diakui dengan menggunakan metode persentase penyelesaian dan diukur dengan metode biaya ke biaya (cost to cost method). Pencatatan yang telah dilakukan oleh PT. X tersebut belum sesuai dengan PSAK No. 34, karena biaya yang dikeluarkan untuk pembangunan diakui sebagai biaya pembangunan, serta pendapatan kontruksi diakui berdasarkan penerimaan kas dari pelanggan. Pengakuan pendapatan yang didasarkan atas penerimaan dari pelanggan mencerminkan bahwa pendapatan yang diakui pada 
periode tersebut tidak dapat mencerminkan pendapatan dengan akurat. Hal ini dikarenakan penerimaan yang diperoleh dari pelanggan merupakan estimasi harga yang disepakati antara perusahaan dengan pelanggan dibagi dengan periode yang telah ditentukan sebelumnya. Sedangkan berdasarkan PSAK No. 23 (Revisi 2015) paragraf 20 dan PSAK No. 34 (Revisi 2015) paragraf 22 tersebut di atas, maka pendapatan sehubungan dengan transaksi pengakuan pendapatan atas jasa kontrak kontruksi jangka panjang tersebut diakui dengan mengacu pada tingkat penyelesaian dari transaksi pada akhir periode pelaporan. Dijelaskan pula pada PSAK No. 34 (Revisi 2015) paragraph 30 bahwa pembayaran berkala dan uang muka yang diterima dari para pelanggan sering kali tidak mencerminkan tahap penyelesaian.

Penerimaan kas dari pelanggan sebagai penerimaan atas penjualan jasa kontruksi merupakan transaksi berkala yang sudah pasti atau telah ditentukan nominal jumlah angka dan kapan terjadinya, yaitu berdasarkan kesepakatan antara perusahaan dengan pelanggan. Sehingga pendapatan tidak dapat diakui berdasarkan penerimaan dari pelanggan tersebut, karena sesuai dengan the matching principle maka pendapatan harus diakui dalam periode yang sama dengan biaya yang dikeluarkan sebagai satu kesatuan.

Pencatatan yang harus dilakukan oleh PT X berdasarkan PSAK No. 34 adalah sebagai berikut:

1. Jurnal untuk mencatat pengeluaran biaya-biaya yang sesungguhnya terjadi

\begin{tabular}{|lr|}
\hline Kontruksi dalam proses & Rp xxx \\
Kas/Material/Akumulasi depresiasi/dll & $\mathrm{Rp} x x x$ \\
\hline
\end{tabular}

2. Jurnal untuk mencatat pengajuan uang muka

\begin{tabular}{|lr|}
\hline Piutang usaha & Rp xxx \\
Penagihan atas kontruksi dalam proses & $\mathrm{Rp} x x x$ \\
\hline
\end{tabular}

3. Jurnal untuk mencatat penerimaan pembayaran uang muka (Termin)

\begin{tabular}{|lrr|}
\hline Kas & Rp xxx & \\
Piutang usaha & & Rp xxx \\
\hline
\end{tabular}

4. Jurnal untuk mencatat pengakuan pendapatan atas kontrak kontruksi yang telah diselesaikan pada tahun $n$

\begin{tabular}{|lc|}
\hline Kontruksi dalam proses & Rp xxx \\
Biaya kontruksi & Rp xxx \\
Pendapatan dari kontrak jangka panjang & Rp xxx \\
\hline
\end{tabular}

5. Jurnal untuk mencatat penyerahan proyek

\begin{tabular}{|lr|}
\hline $\begin{array}{l}\text { Penagihan atas kontruksi dalam proses } \\
\text { Kontruksi dalam proses }\end{array}$ & Rp xxx \\
\hline & $\mathrm{Rp} x x x$ \\
\hline
\end{tabular}


Metode pengakuan pendapatan persentase penyelesaian dengan pendekatan biaya atau cost to cost, menentukan besarnya persentase dengan cara membandingkan total biaya yang sudah dikeluarkan dalam pengerjaan proyek berjalan (total biaya aktual) dengan taksiran total biaya proyek atau rencana anggaran biaya yang sudah diperkirakan sebelumnya untuk menyelesaikan proyek. Pendekatan biaya atau cost to cost mengakui pendapatan dengan memerhatikan besarnya biaya yang terjadi atau usaha yang telah dicurahkan atau dikeluarkan untuk mencapai tahap penyelesaian pekerjaan proyek dalam periode berjalan. Dalam metode ini biaya-biaya yang terjadi dapat dihubungkan dengan pendapatan kontrak yang diakui dalam periode tersebut, sehingga pendapatan, beban dan laba dapat dilaporkan secara proporsional. Persentase penyelesaian untuk perhitungan pengakuan pendapatan yang dilakukan dengan menggunakan metode pendekatan biaya atau cost to cost dapat dihitung dengan menggunakan rumus sebagai berikut (Novianti. 2014:13):

\begin{tabular}{|l|}
$\begin{array}{l}\text { Biaya-biaya yang dikeluarkan } \\
\text { Sampai akhir periode berjalan } \\
\text { (Total Biaya } \text { Actual) }\end{array}$ \\
\hline $\begin{array}{l}\text { Taksiran total seluruh biaya } \\
\text { Penyelesaian yang diperkirakan } \\
\text { (Rencana Anggaran Biaya) }\end{array}$ \\
\hline
\end{tabular}

Persentase penyelesaian dalam suatu periode yang sudah dihitung akan dikalikan dengan total nilai kontrak proyek untuk mendapatkan hasil pendapatan yang diakui untuk periode tersebut. Persentase yang diperoleh dari perbandingan biaya-biaya yang dikeluarkan selama periode berjalan terhadap taksiran jumlah seluruh biaya atau rencana anggaran biaya, diterapkan pada jumlah seluruh pendapatan atau taksiran seluruh laba kotor dalam kontrak, untuk mendapatkan jumlah pendapatan atau jumlah laba kotor yang diakui sekarang (Novianti. 2014:13).

Berdasarkan penjelasan PSAK No. 34 maka dapat diperoleh hasil data keuangan PT. X terkait pembangunan mall yaitu sesuai dengan ringkasan sebagai berikut: 

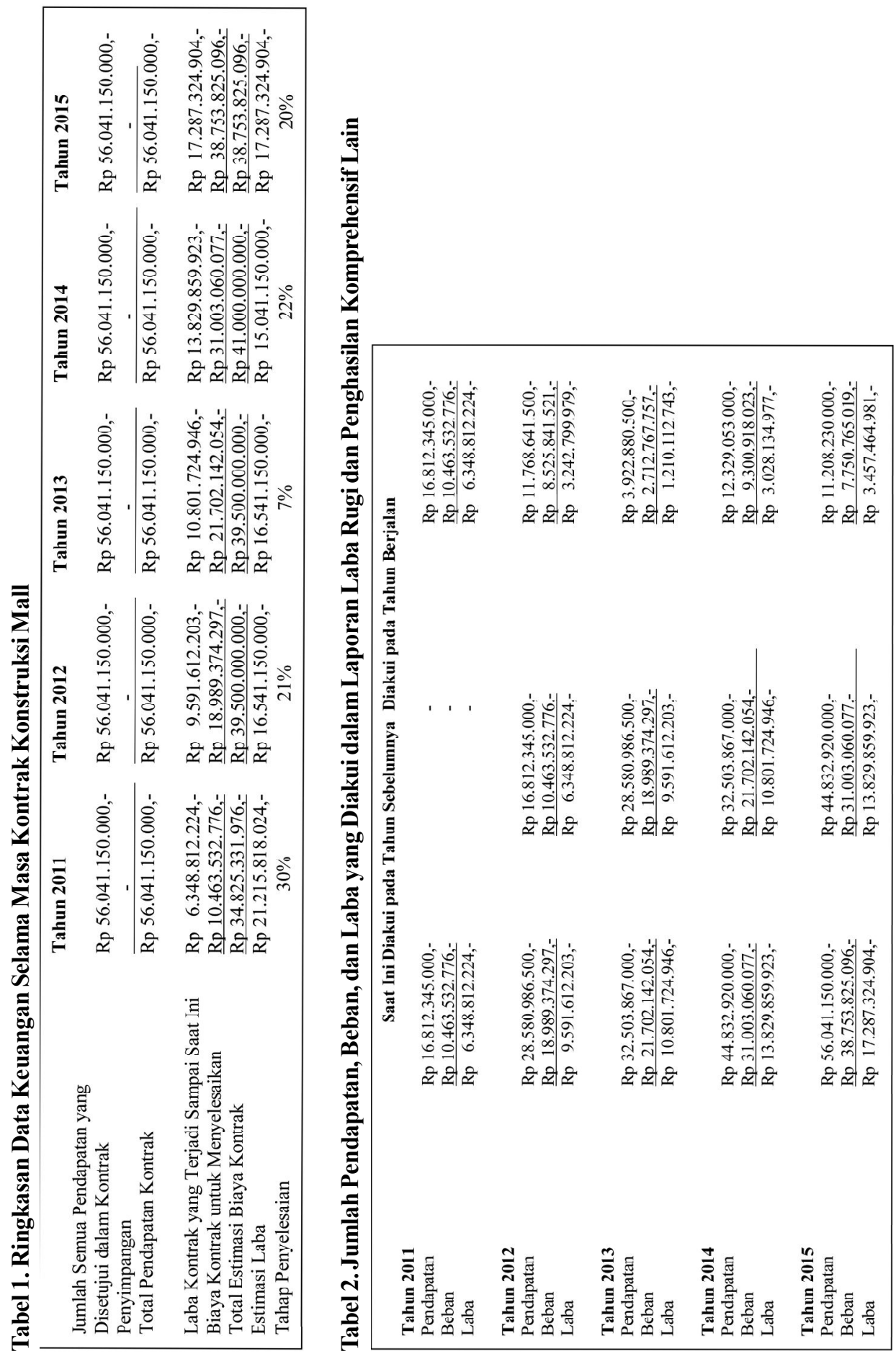

El-Muhasaba, Vol. 7, No 1, Januari 2016 
Jumlah pendapatan, beban, dan laba yang diakui dalam laporan laba rugi dan penghasilan komprehensif lain dalam jangka waktu 5 tahun adalah sebagaimana tabel 2.

\section{Pengakuan Pendapatan Perspektif Islam}

Berdasarkan penggalan surat al-Baqarah ayat 282 yang artinya "Hai orangorang yang beriman, apabila kamu bermu'amalah tidak secara tunai untuk waktu yang ditentukan, hendaklah kamu menuliskannya." maka, terjadinya suatu transaksi secara tidak tunai hendaklah dicatat. Kontrak kontruksi yang terjadi pada PT. X yang merupakan kontrak kontruksi jangka panjang belum dilakukan pencatatan atas adanya pengakuan kewajiban kepada pelanggan. Hal ini belum sesuai dengan penggalan ayat al-Baqarah 282. Selain itu, pengakuan yang dibenarkan dalam al-Quran yakni ketika suatu transaksi telah terjadi maka harus dicatat agar diketahui denga jelas kewajiban maupun hak dari suatu perusahaan, serta agar memiliki kekuatan hukum. Hal ini juga memudahkan suatu perusahaan untuk mengingatkan entitas lain yang bertransaksi jika terjadi keterlambatan dalam melakukan pembayaran. Pengakuan pendapatan ini sesuai dengan dengan PSAK no. 34 yaitu dengan berdasarkan metode persentase penyelesaian. Karena dijelaskan pada surah al-Baqarah 282 pula bahwa ketika transaksi telah terjadi maka hendaklah dicatat. Selanjutnya, pengakuan pendapatan dengan metode persentase penyelesaian ini juga sesuai dengan prinsip keadilan yang dijelaskan pada suarah al-Jazilah ayat 22. Ketika perusahaan telah melakukan pekerjaannya, maka sudah menjadi hak perushaan untuk mengakui pendapatan berdasarkan pekerjaan yang telah diselesaikan. Prinsip ini juga sesuai dengan prinsip penandingan (The Matching Principle).

\section{SIMPULAN}

Berdasarkan pembahasan dan analisis yang telah dilakukan oleh penulis, maka dapat disimpulkan: Pencatatan yang telah dilakukan oleh PT. X tersebut belum sesuai dengan PSAK No. 34 tentang Akuntansi Kontrak Kontruksi. Hal ini disebabkan oleh biaya yang dikeluarkan untuk pembangunan diakui sebagai biaya pembangunan, serta pendapatan kontruksi diakui berdasarkan penerimaan kas dari pelanggan. Pengakuan pendapatan yang didasarkan atas penerimaan dari pelanggan mencerminkan bahwa pendapatan yang diakui pada periode tersebut tidak dapat mencerminkan pendapatan dengan akurat. Hal ini dikarenakan penerimaan yang diperoleh dari pelanggan merupakan estimasi harga yang disepakati antara perusahaan dengan pelanggan dibagi dengan periode yang telah ditentukan sebelumnya. Sedangkan berdasarkan PSANo. 23 (Revisi 2015) paragraf 20 dan PSAK No. 34 (Revisi 2015) paragraf 22 tersebut di atas, maka pendapatan sehubungan dengan transaksi pengakuan pendapatan atas jasa kontrak kontruksi jangka panjang tersebut

diakui dengan mengacu pada tingkat penyelesaian dari transaksi pada akhir periode

El-Muhasaba, Vol. 7, No 1, Januari 2016 
pelaporan. Selain itu, PT. X tersebut tidak mengakui pendapatan secara proporsional pada setiap akhir periode, pendapatan yang diakui adalah sebesar penerimaan dari pelanggan.

Berdasarkan PSAK No. 23 dan PSAK No. 34 (Revisi 2015) menjelaskan bahwa bahwa jika hasil kontrak kontruksi dapat diestimasi secara andal, maka pendapatan kontrak dan biaya kontrak yang berhubungan dengan kontrak konstruksi diakui masing-masing sebagai pendapatan dan beban dengan memerhatikan tahap penyelesaian aktivitas kontrak pada tanggal akhir periode pelaporan. Dengan menggunakan metode persentase penyelesaian dalam mengakui pendapatan pada kontrak kontruksi jangka panjang, maka pendapatan yang diakui pada periode tersebut lebih mencerminkan keadaan yang sesungguhnya terjadi pada perusahaan. Penerapan metode pengukuran tingkat penyelesaian kontrak suatu kontruksi dengan menggunakan metode biaya ke biaya (cost to cost method) melakukan pencatatan nilai pendapatan (revenue) berdasarkan perhitungan proporsi biaya kontrak yang dikeluarkan. Hal ini sesuai dengan the matching principle yang menyatakan bahwa biaya yang dikeluarkan harus diakui dalam periode yang sama dengan pendapatan sebagai satu kesatuan. Sehingga pendapatan dan laba kotor kontruksi diakui lebih tepat dalam rangka penyajian keuangan yang wajar yang berguna untuk memberikan informasi lebih akurat dalam pengambilan keputusan (Ratunuman, 2013:582). Dengan menggunakan metode persentase penyelesaian, maka pengakuan pendapatan tersebut telah sesuai dengan PSAK khususnya PSAK No. 23 tentang Pendapatan dan PSAK No. 34 tentang Kontrak Kontruksi, serta telah memenuhi salah satu karakteristik kualitatif laporan keuanga yaitu keandalan yang merupakan bagian dari kerangka konseptual menurut PSAK.

\section{DAFTAR PUSTAKA}

Al Quran dan Terjemahnya.

Ankarath, dkk. 2012. Memahami IFRS standar Pelaporan Keuangan Internasional. Jakarta: PT INDEKS.

Baqir, Muhammad Ash-Shadr. 2008. Buku Induk Ekonomi Islam. Jakarta: Zahra.

Ghony, M. Djunaidi, dan Fauzan Almanshur. 2012. Metode Penelitian Kualitatif. Jogjakarta: Ar-Ruzz Media.

Harahap, Sofyan Syarif. 2007. Teori Akuntansi. Jakarta: PT Rajagrafindo Persada.

Harahap, Sofyan Syarif. 2008. Teori Akuntansi Syariah. Jakarta: PT Rajagrafindo Persada.

Novianti, M.D. 2014. Penerapan Metode Pengakuan Pendapatan Kontrak Jangka Panjang pada PT. Adhikarya Jaya Mandiri. Jurnal Ilmu \& Riset Akuntansi. Volume 3 No. 8. Surabaya: Sekolah Tinggi Ilmu Ekonomi Indonesia Surabaya.

Ratunuman, S.M. 2012. Analisis Pengakuan Pendapatan dengan Persentase Penyelesaian dalam Penyajian Laporan Keuangan PT. Pilar Dasar. Jurnal EMBA. Volume 1 No. 3. Manado: Universitas Sam Ratulanmgi Manado.

Santoso, I. 2009. Akuntansi Keuangan Menengah (Intermediate Accounting). Bandung: PT Refika Aditama. 
Sidi Moh, dan Priadana, Saludin Muis. 2009. Metodologi Penelitian Ekonomi dan Bisnis. Yogyakarta: Graha Ilmu.

Widiarti, A. 2010. Akuntansi Konstruksi untuk Perusahaan Property dan Developer. Yogyakarta: STMIK AMIKOM.

Wijaya, H., dkk. 2015. Analisis Pengakuan Pendapatan dan Beban dalam Penyajian Laporan Laba Rugi pada PT. Karya Jaya Dedy Mulia. Palembang: STIE MDP.

Zulnaidi. 2007. Metode Penelitian Kualitatif. Bandung: Erlangga.

http:/tafsirq.com/2-al-baqarah/ayat-282. 16 Juni 2016.04.00 WIB

El-Muhasaba, Vol. 7, No 1, Januari 2016 